\title{
NEW SPECIES OF THYRIDIDAE, URANIIDAE, AND GEOMETRIDAE, FROM THE ORIENTAL REGION.
}

\author{
By W. WARREN, M.A., F.E.S. \\ FAMILY THYRIDIDAE.
}

\section{Canaea hyaena spec. nov.}

Forewing: grey on an ochreous ground, covered with short striae of darker grey between the veins and crossed by several obscurely marked dark grey lines; the ochreous ground-colour appears only along the costal edge, which is marked with dark grey dots and beyond middle with three dark streaks, and along hindmargin at base of fringe, which is otherwise dark grey; a small round hyaline spot below the lower end of cell between veins 2 and 3 ; sometimes the central area is clonded with grey; traces of large pale spots between veins before the margin.

Hindwing: similar, but paler; the cross markings more distinct, and rufoustinged; a fine ferruginous line along hind margin; inner margin pale ochreous; fringe of inner margin and a row of hairs along vein 1 pale ochreous.

Underside speckled with brown; forewing with three brown patches, two postmedian, below costa and above inner margin, the third below apex.

Head, thorax, abdomen, and legs dark grey; abdomen beneath ochreous.

Expanse of wings : $28-30 \mathrm{~mm}$.

$3 \delta \delta, 4 q q$ from Guizo Island, Solomons, November 1903 (Meek).

\section{Canaea venustula spec. nov.}

Forewing: grey, covered with rough transverse darker grey reticulations, and crossed by five or six irregular darker bands, which on inner margin become reddish; the antemedian, median, and postmedian are vertical ; two towards apex are less distinct, shorter, and more or less broken up ; the base and costa are greybrown; the costal edge white, with numerons dark dots; from apex to middle a row of red marginal spots between veins; fringe dark grey, the tips below the middle white.

Hindwing: with the bands red, the marginal line continuons, red; fringe dark grey, white-tipped thronghout, and varied in places with red scales.

Underside paler, with all the markings much clearer ; apex of forewing tinged with red.

Head and thorax grey-brown like the wings; abdomen red, with anal tuft ochreous yellow; abdomen beneath and legs pale, thickly speckled with grey-brown.

Expanse of wings : $22 \mathrm{~mm}$.

1 o from Upper Aroa River, British New Guinea, January 1903 (Meek).

\section{Hypolamprus subumbrata spec. nov.}

Forewing: pale flesh-coloured ochreous, crossed by pale brown wavy lines, with faint strigae between them; the lines roughly in pairs and after the first pair becoming oblique inward parallel to hindmargin ; the third pair above the middle 
diverging funnel-shaped to the costa at one-half and three-fourths; the fonrth pair, which is submarginal and wider below, is preceded and followed by paler bands containing a row of faint striae down their centre; the costa is diffusely whitish grey.

Hindwing: similar, but the basal lines clonded.

Underside duller, more grey ; costal balf of forewing to two-thirds shaded with dull brown.

Head, thorax, and abdomen like wings ; face and palpi dark brown.

Expanse of wings : $36 \mathrm{~mm}$.

1 \& from Maymyo, Shan States, June-August 1902 (Hanxwell).

Veins 8, 9 of forewing are stalked, and I have provisionally, therefore, placed the species in Hypolamprus, though it appears somewhat out of place.

\section{Striglina floccosa spec. nov.}

Forewing: dull brick-red, tinged along the costa with olive-fuscons, and with the transverse streaks and reticulations of the same colour; these form many indistinct eurved lines parallel to hindmargin, those beyond middle bluntly angled on vein 4, that in the middle of wing slightly thicker and more conspicnous, containing an obscure dark cell-mark; fringe brick-red, with the tips somewhat darker.

Hindwing: very similar; along inner margin the fringe and a bed of hairs to vein 1 fluffy pink.

Underside with basal half of wings pink, onter half fulvous; on the discocellular of forewing a large spot of blackish and grey scales; the inner margin pink without striae; hindwing with base and inner half of wing covered with fluffy pink hairs.

Head and shoulders red-brown; thorax and abdomen redder; legs fulvous red, the tarsi brown : forelegs with tibiae and tarsi dark brown, the latter ringed with white, the former with a large flake of snow-white.

Expanse of wings : $35 \mathrm{~mm}$.

1 o from Upper Aroa River, British New Guinea, April 1903 (Meek).

This species is nearest superior Butler, which is, however, dull ochreous in colour, and has a distinct pencil of hairs on the hindwing on vein 1 .

\section{Striglina scintillans spec. nov.}

Forewing: bright vermilion red, much brighter than in S. recersa Warr., which otherwise it greatly resembles; costa narrowly brown, in reversa the costal area as far as subcostal vein is dark; lines and reticulations much as in reversa, but much fainter ; between the veins series of small round yellow spots alternate with the red; in reversa the whole wing is red; spots of the marginal line and the transverse reticulations of the submarginal and postmedian series stndded with bright metallic scales.

Hindwing: the same; fringe of inner margin yellow, not reddish.

Underside red, not pinkish-ochreous, as in reversa.

Head, thorax, and abdomen vermilion; abdomen beneath and legs yellowochreous; forelegs in front, and middle legs externally, pectus, and palpi vermilion.

Expanse of wings : के 24-26 mm.; $+30 \mathrm{~mm}$. 
$4 \delta \delta, 1 \uparrow$ from Upper Aroa River, British New Guinea, Febrnary-April 1903 (Meek).

Taken along with $5 \delta \delta$ and $7 q q$ of $S$. reversa, not one of which bears the slightest trace of metallic scaling. In both sexes this species is smaller than reversa.

FAMILY URANIIDAE.

\section{SubFamily EPIPLEMINAE.}

6. Decetia uniformis spec. nov.

Forewing: drab, densely dusted with leaden-grey speckling; a dark discocellnlar spot; in some cases a very faint rust-colonred obliqne line can be seen, placed as in dichromata, and the course of the submarginal spots is traced in the same colour ; fringe dark rust-colonr.

Hindwing: the same.

Underside equally uniform.

Head, thorax, and abdomen concolorous.

Expanse of wings : $48-52 \mathrm{~mm}$.

2 ठै ठ, 3 $q$ from Treasury Island, Solomons, August 1901 (Meek).

Decetia dichromata Wlk. in all its localities is subject to great general variation, and the sexes in particnlar differ from each other; in the present species the sexes are exactly alike, and there is not the slightest trace of variation in any of the five examples. I must therefore, for the present, consider them to form a separate species.

\section{Epiplema triangulifera spec. nov.}

Forewing: fawn-colour, finely speckled with grey ; the lines dark brown, all three more or less vertical and parallel ; the first obscure at one-third, not marked above subcostal vein ; second at two-thirds, thick ; third submarginal, not reaching costa ; cell-spot brown, linear ; fringe concolorous, mottled with dark beyond veins.

Hindwing: with outer line bluntly angled at middle, edged externally by a pale line; a brown line along median vein from base, forming with the brown discal line a distinct brown triangle in midwing; a dark brown cloud along hindmargin from upper tooth to below lower tooth, before which it is crossed by a pale line.

Underside of forewing dull brown, of hindwing ochreous speckled with brown; the outer line brown and distinct in both wings.

Face and palpi black ; vertex, thorax, and abdomen concolorous with wings.

Expanse of wings : $19 \mathrm{~mm}$.

$2 \delta \delta$ from Guizo Island, Solomons, November 1903 (Meek). I have seen a $\delta$ also from Guadalcanar, Solomons.

Forewing with hindmargin merely indented between veins 6 and 3 ; hindwing with short teeth at veins 4 and $\%$.

\section{Monobolodes schistacea spec. nov.}

Forewing: deep slate-colour; the lines black, placed exactly as in M. nigrescens Warr. from Fergusson Island, but without any yellow scaling; the onter line 
somewhat inbent in middle towards the angle of inner line, which is only distinct towards inner margin; the black line at base of fringe swollen towards apex.

Hindwing: with the black line central and continuous; the abdominal fold bluish white, the pencil of hairs, when expanded, cream-coloured.

Underside paler slate-colour, especially in the $\delta$, where the hindwing becomes bluish white towards anal angle.

Head, thorax, and abdomen all dark slate; anal tuft in $\delta$ white.

Expanse of wings: $26 \mathrm{~mm}$.

4 ठे ठै, 4 $q$ from Guizo Island, Solomons, November 1903 (Meek); and 1 ठ from Treasury Island, Angust 1901 (Meek).

\section{FAMILY GEOMETRIDAE.}

\section{SubFamly OENOCHROMINAE.}

\section{Arhodia retractaria ab. carnea nov.}

Differs from the type form of retractaria Wlk. in being without markings of any kind on the upperside, except a slight dark cell-spot; the hindwing is deep rosy, with the fringe of hind and inner margin white; the forewing shows an admixture of lnteous; fringe of forewing dark ferruginous.

Underside paler, especially towards base; forewing with an oblique curved purple blotch from vein 2 to 6 , bounded by an indistinct brownish outer line from costa before apex; discocellular and veins $3,4,5$, all marked with purple; space between them pale pink, paler than rest of wing; hindwing with indistinct outer line in costal half of wing.

Head, thorax, and legs pale flesh-colonr ; abdomen whitish, tinged on dorsum with flesh-colour.

Expanse of wings : $60 \mathrm{~mm}$.

1 \& Toowoomba, Brisbane district, Queensland.

In forewing the hindmargin is slightly concave beneath the apex and blnntly elbowed at vein 5 , thence oblique and straight; hindwing with margin and both angles rounded.

\section{Sarcinodes subfulvida ab. olivata nov.}

I described subfulvida from Kiriwini, Trobriand Islands (Nov. Zool. iii. p. 280) (1896), from 3 o $\delta$, and since then bave met with examples from Ron Island, St. Aignan, and New Guinea. In nearly all these, both $\delta \delta$ and $q q$, the prevailing tint, as in the type, has been red; but in $2 \delta \delta$ from the Upper Aroa River, British New Guinea, the colouring was much darker and the red tinge almost absent. I have lately seen a $q$ from the same locality, corresponding to these $\delta \delta$, which, as suggesting at least a very distinct local race, I describe as ab. olivata.

Forewing: dark olive, suffused with fuscous, and overlaid from base to onter line by dark slaty grey and white scales, these latter prevailing along inner margin and at costa before the outer line; the inner and median lines are distinct but diffuse; the onter line is double, both arms being dark olive, marked with clear white spots on the veins and towards inner margin filled in with white; the waved submarginal line has the lunules marked with whitish and black scales; and the fringe is dark olive.

Hindwing: with the double line filled in with white througbont, closely 
preceded by a large round white cell-spot; the rest as in forewing, but the dark fringe is preceded by white scales, and the inner margin and fringe are whitish.

The underside is pinkish brown with all the markings indicated by darker shades; the costa of forewing is marked with white scales and a white blotch before apex ; all the lines are marked by fine pale dashes on veins, and the white cell-spot of hindwings is plain, with another white spot below it.

Shoulders, vertex, and npper half of face brownish olive; lower part of face and palpi dark grey; thorax and abdomen grey and olive mixed; base of palpi beneath and pectns fulvous-tinged; legs blackish spotted with white.

Expanse of wings : $60 \mathrm{~mm}$.

Upper Aroa River, British New Guinea (A. S. Meek).

A large pale discal spot occurs also in S. vultuuria Guen. from Borneo, but on the underside of hindwing only ; and a similar spot on the upper side of forewing is mentioned in the description of $S$. perakaria Swinhoe; both these examples being, like the present one, $q q$.

\section{SubFamily GEOMETRINAE.}

\section{Thalassodes subviridis spec. nov.}

Forewing: bright pale green, with a few faint pale transverse striae, most distinct in the marginal area; costa cream-colour ; a fine oblique whitish inner line only visible below median vein; a nearly vertical straight outer line from below costa just beyond middle; fringe yellow.

Hindwing: with outer line only, distinct from costa to vein 3 , where it is angled and becomes fainter.

Underside mealy pale green; the costa of forewing ochreous.

Head, thorax, and abdomen all green; vertex snow-white; basal half of anteunal shaft white, apical half green, the pectinations grey-green; abdomen with a pale dorsal line.

Expanse of wings : $27 \mathrm{~mm}$.

$1 \delta$ from Christmas Island (Andrews).

Nearest to Th. dorsilinea Warr. from New Gninea, but smaller and mnch greener on the underside; the antennae are heavily pectinated, and quite threefourths of the length of forewing; hindmargin of hindwing bluntly bent at middle.

\section{Subfamily STERRHINAE.}

\section{Mesotrophe ? subrubrata spec. nov.}

Forewing: fawn-colonr, densely sprinkled with dull red, partially confluent, dots and striae; costa brown-black at base, paling towards apex ; lines of the same colour, but obscure; first from one-fifth of costa to one-fourth of inner margin, waved and interrupted ; onter from nearly three-fourths of costa to three-fourths of inner margin, lunulate-dentate, outeurved in middle; a vertical thick waved olivebrown median shade; cell-spot minute, white with a dark ring; submarginal line obscure, but preceded and followed by black lnnular clouds below costa and above inner margin ; marginal lunules blackish ; fringe concolorous.

Hindwing: with inner line marked by a black blotch at one-fourth of inner margin ; cell-spot minute, white; the rest as in forewing, but the black clouds in 
submarginal field confined to anal region only, forming there a large subquadrate patch.

Underside uniform dull rosy.

Palpi ochreous below, bright pink above; face deep red; fillet and antennae ochreous; vertex and base of shoulders black-brown ; thorax and base of abdomen like wings ; anal segments of abdomen and the underside paler, more ochreous.

Expanse of wings : $40 \mathrm{~mm}$.

1 from Guizo Island, Solomons, November 1903 (Meek).

Probably a Mesotrophe.

\section{SUBFAMILY HYDRIOMENINAE.}

\section{Gonanticlea deleta spec. nov.}

Exactly like Gonanticlea sublustris Warr., except that the central fascia is merely denoted by the pale limiting lines marked by black specks on the veins, the broad black bands of sublustris being restricted to the costal area as far as vein 6 ; the whole wing is thus reddish grey-brown, with a slight leaden purple tint beyond onter line. If this had been the only difference, however, I should have considered it merely an aberrational form; but the forewings of the $\delta$ on the underside are withont the pilose scaling by which sublustris is characterised.

Expanse of wings : o $39 \mathrm{~mm}$.; i $35 \mathrm{~mm}$.

1 đ, 1 from Upper Aroa River, British New Guinea, March 1903 (Meek) taken along with a typical $\delta$ example of sublustris.

From the black costal markings the insect superficially assumes the likeness of a large Lygranoa.

\section{SUBFAMILY TEPHROCLYSTIINAE.}

\section{Neoscelis cristata.}

Gymnoscelis cristata Warr., Nov. Zool. iii. p. 229 \& (1896).

Neoscelis rivula Hmpsn., Journ. Bombay N. H. Soc. xiv. p. 639. no. 3748b. \& fig. (1902).

The description of $N$. rivula Hmpsn. and the figure apply perfectly to G. cristata Warr. sunk on p. 640 by Hampson to G. deleta. The insect also occurs at Penang, in the Andamans (coll. Swinh.), and in New Guinea; but all the examples are $+q$. On examination of the New Guinea examples I find that 7, 11, 10, 8, 9 of forewings are stalked together as in Neoscelis Hmpsn. and Adeta Warr., which latter will probably have to fall to Neoscelis. But at present there are considerable differences between the genera. In Adeta semifascia Warr. and in the New Guinea examples of cristata the hindtibiae have a single long middle spur, and the antennae of the $q$ are simple, not ciliated; vein 5 rises from the centre of the discocellular, and 6 from the depressed upper end of the cell ; further, in semifascia, the type of Adeta, vein 11 does not anastomose with 12, as is the case in cristata.

\section{Subfamly TRICHOPTERYGINAE.}

\section{Anthierax subfulva spec. nov.}

Agrees in most points with the description of A. malaca Meyr. (Remodes) from New Gninea, but the palpi are externally coal-black, not green; the onter lobe of the hindwing of $\delta$ is blunt, and below, the tuft in the fringe between the onter lobe 
and the next is dull fulvons. In the forewing the darker green transverse lines are all tinged with blackish along the submedian interval, the cell and space beyond it between veins 4 and 6 , and also between veins 6 and 7 ; the cell-spot is black, not green as in malaca. The abdomen is greenish cinerous. It agrees with malaca in having white spots behind the eyes and a black lateral mark on the shoulders.

Expanse of wings : $36-40 \mathrm{~mm}$.

$2 \delta$ o from Guizo Island, Solomons, November 1903 (Meek).

\section{Anthierax subnigrata spec. nov.}

Forewing: green, with darker green waved transverse lines, which beyond middle are regularly dentate-lunnlate, mnch more regular than in A. subfulva; of the four basal lines the second is slightly purplish-tinged; the four lines forming the central fascia, one before the green cell-spot and three beyond, are all purplishtinged, and so is the submarginal line and the teeth of the line preceding it, as well as the marginal spots; the marginal space is slate-colour, quite bluish in the middle, and the fringes slate-colour, with white spots beyond the veins.

Hindwing: purplish grey with long grey hairs from the base of wing; the fringe of inner margin long and glossy black, of onter margin ochreons and shorter.

Underside of forewing greenish cinereons ; of hindwing purplish black.

Head, palpi, and thorax green; abdomen cinereons olive; white spots behind the eyes, but no black marks on shoulders.

Underside of abdomen on basal half and inside of the tuft of hair on hindtibiae blackish.

Expanse of wings : $30 \mathrm{~mm}$.

$1 \delta$ from Guizo Island, Solomons, November 1903 (Meek).

Qnite distinct from the preceding species subfulva.

\section{Sauris angusta spec. nor.}

Forewing: whitish green, with dark green cross-lines; the centre of the wing is crossed by a wide sinnous band of pale green containing the green cell-spot; between this and the base are six waved ontwardly oblique green lines, of which the second is tinged with purplish; beyond it are fonr lunulate-dentate green lines, of which the innermost (not, as nsual, the ontermost) is purplish-tinged; the snbmarginal line is slightly purplish, as are the marginal spots; fringe worn.

Hindwing: pale grey, greenish-tinged, a little darker towards margins.

Underside of forewing greenish grey, of hindwing brownish fulvous, the scales thick and coarse.

Head, palpi, thorax, and abdomen green, the last paler and greyer. Antennae glossy, purplish, fulvous beneath; the upper surface sinuate, as in Helminthoceras.

Expanse of wings : $26 \mathrm{~mm}$.

1 ठै from Guizo Island, Solomons, November 1903 (Meek).

The hindwing is very narrow, the costa and inner margin only slightly diverging ; the hindmargin is slightly prominent at one-third from apex and one-third from anal angle ; there are only four veins; the costal and subcostal separate at one-third from base, the costal running to apex and the subcostal to the upper prominence; vein 5 is absent ; the median runs into the lower projection and vein 3 , which rises 
near base, into the anal angle; no discocellular is visible; the lobe at base of inner margin is suberect, and about one-fourth of the length of the margin. In the shape and thick scaling of the hindwing the insect approaches Dystypoptila triangularis Warr. from Sumatra.

\section{SubFamily DEILINIINAE.}

\section{Peratophyga bifasciata spec. nov.}

Forewing: pale yellow; the markings dark brown; a curved fascia just before middle and a broad marginal border, connected by a brown streak from base along vein 1 , below which on the inner margin the yellow of the gronnd-colour reappears as broken patches; costa at base also brown; the inner edge of the dark border projects shortly inwards on median vein, and the yellow space before it is traversed by a row of brown vein-dots; submarginal line indicated by slight yellow marks on the veins along the centre of the dark border, with a yellow spot at apex; marginal yellow spots at end of veins; fringe brownish.

Hindwing: like forewing.

Underside the same, but the yellow paler and clearer, withont any spots.

Head, thorax, and abdomen brown; second segment and anal tuft yellow; abdomen beneath and legs yellowish.

Expanse of wings : $18 \mathrm{~mm}$.

$1 \delta$ from Cheng Mai, Hainan, August 1902.

\section{Subfamily ABRAXINAE.}

\section{Abraxas parvipunctata spec. nov.}

Forewing: cream-white; the base of wing on costa yellow ; costal area with numerous small round grey spots, irregularly disposed and in places confluent; a few scattered ones in cell, and a larger one on discocellular; at two-thirds of costa a small oblique grey blotch followed by a small spot on vein 6 ; two submarginal series of spots parallel to hindmargin, the inner small and placed on the veins, the outer larger between them, coalescing laterally above middle with a marginal row, below it interrupted.

Hindwing: with the three outer series of spots only, all separate.

Underside similar, but all the spots larger and better defined.

Head, thorax, and abdomen yellow, the last with dark spots; palpi and legs externally dark fuscous.

Expanse of wings : $50 \mathrm{~mm}$.

1 f from Dili, N.E. Sumatra.

In appearance nearest to $A$. virginalis Butler.

\section{SubFamly SEMIOTHISINAE.}

Loxotephria gen. nov.

Forewing: costa faintly curved; hindmargin obliquely curved. blunt.

Hindwing: with hindmargin only slightly curved; apex rounded; anal angle

Antennae simple in both sexes, with very short pubescence in $\delta$; forehead 
with projecting peak of scales; palpi porrect, well-scaled, the segments indistinct; tongue and frenulnm present; hindtibiae with four spurs; submedian vein of forewing of $\delta$ swollen at base into a small fovea.

Neuration : forewing, cell nearly half the length of wing; discocellular vertical, but strongly oblique below ; first median nervule at four-fifths, second just before third; radials normal, 5 slightly above centre; 7, 8, 9 stalked; 10 anastomosing at a point with 11, which rises from 12: hindwing, 7 and 3 well before angles of cell.

Type: Loxotephria olivacea spec. nov.

Tephrina? convergens Warr., from West China, described from a $q$ only (Nov. Zool. vi. p. 61, 1899), should be placed in this genus.

\section{Loxotephria olivacea spec. nov.}

In markings resembling convergens Warr., but the ground-colour of the wings is olive-yellowish, sometimes quite green along cell and below costa of forewing; costa with short purplish striae; first line red or red-brown, the angle in cell tonching the red cell-mark; outer line red-brown, externally edged with lustrous pearly scales; submarginal line olive-green; the marginal space beyond it darker, and covered with lnstrons violet; fringe brown, with red-brown basal and middle lines.

Hindwing: without the basal line ; the other two straight and parallel.

Underside deep bright yellow ; striae and lines purple-red ; the marginal clond purplish-violet, and stronger in the $\delta$ than in the $q$.

Head, thorax, and abdomen like wings ; face brown.

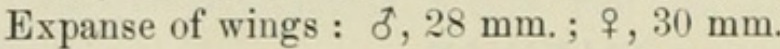

Several examples from Manchyo and Secha, Hainan, May and June 1902.

L. convergens from West China is darker, browner, and has a brown subcostal streak through the angles of the lines of forewing.

\section{SubFAMILy ASCOTINAE.}

\section{Amblychia schistacea spec. nov.}

Forewing: dark slate-colour; the lines and interval between onter and submarginal lines deeper; inner line curved, projecting strongly above median, and less prominently below, edged inwardly by paler slate-colour and whitish. There are also some whitish flakes on costa and in cell between the inner and median lines; interval between median and onter lines from costa to vein 3 occupied by a cream-white blotch speckled with slate-colour, followed below 3 by a large white blotch filling up the lunule of median line; the lunule below it white-edged; cell-spot black, nearly touching the inner edge of the white blotch ; fringe brown-slate.

Hindwing: similar, with only a few whitish flakes beyond antemedian line, those in cell most conspicuous, and a white lunule between veins 7 and 8 .

Underside with basal area of both wings pale greyish slate, varied with dull ochreous and speckled with darker; outer area of both wings slaty fuscous, the white markings well expressed in forewing, obscurely in hindwing.

Head and shoulders dark slaty fuscons ; patagia, thorax, and abdomen pale dirty ochreous.

Expanse of wings : $104 \mathrm{~mm}$.

$1 \delta$ from Batchian (Waterstradt). 


\section{Catoria lucidata spec. nov.}

Forewing: white, with olive-green speckling only; the lines, double, dark olive-green, placed much as in delectaria Wlk., but the outer line conspicnously angled on vein 6 , not rounded; lunules of the shade preceding submarginal line marked with blackish beyond cell and between veins 7 and 8 , and 2 and 3 ; marginal lunules and cell-spot black; fringe white.

Hindwing: like forewing; cell-spot a black point, not an ocellus.

Underside greenish brown clonded with velvety black before the white spaces of the hindmargin, which are bright white, not cloudy as in delectaria ; cell-spot of forewing velvety black, large and round; of hindwing only a black point.

Head and thorax pale greenish; abdomen white, the basal segments edged with brownish scales : antennal pectinations rufous ; in delectaria they are fuscous.

Expanse of wings : $48 \mathrm{~mm}$.

1 of from Guizo Island, Solomons, November 1903 (Meek).

\section{REMARKS UPON SOME THEORIES IN REGARD TO THE MIGRATION OF BIRDS.}

\section{BY W. RUSKIN BUTTERFIELD.}

I SUPPOSE most persons who are acquainted with the literature of birdmigration must feel that few of the theories with which the subject is burdened compel assent. In the present paper I venture to put together under the various headings such suggestions as appear to me to be of moment.

\section{INCENTIVES TO MIGRATION.}

The awakening of the impulse of migration in spring and autumn is often confused with the proximate cause or causes of the separate journeys by which the whole migration in each direction is accomplished. The inherent stimulus is doubtless felt in many, and perhaps in most, birds before the northward or southward movement is embarked upon. The immediate incentive to migration need not be the same for all species of migrants, nor indeed for all the individuals of the same species; moreover, the incentive to spring migration need not be the same as the incentive to autumn migration. From the confusion mentioned above, some writers have songht uniform causes competent to account for each of the two great movements in all species. The incentives to these movements may result, as I shall hope to show, from a variety of causes acting alone or in concert, and in seeking them we need not concern ourselves with the original cause of migration.

Taking the autumn migration first," scarcity of food is thought by many authors to afford a sufficient explanation of the desertion of the summer quarters by most species, although it is allowed that this cannot be the sole cause, since it not infrequently happens - as in the case of our Song Thrush-that a breeding

* For convenience, the series of journeys constituting each of the two great seasonal movements requires to be denoted by a separate term. 


\section{$2 \mathrm{BHL}$ Biodiversity Heritage Library}

Warren, William. 1905. "New species of Thyrididae, Uraniidae, and Geometridae, from the Oriental Region." Novitates zoologicae : a journal of zoology in connection with the Tring Museum 12, 6-15.

https://doi.org/10.5962/bhl.part.24265.

View This Item Online: $\underline{\text { https://www.biodiversitylibrary.org/item/23228 }}$

DOI: https://doi.org/10.5962/bhl.part.24265

Permalink: https://www.biodiversitylibrary.org/partpdf/24265

\section{Holding Institution}

Natural History Museum Library, London

\section{Sponsored by}

Natural History Museum Library, London

\section{Copyright \& Reuse}

Copyright Status: Public domain. The BHL considers that this work is no longer under copyright protection.

This document was created from content at the Biodiversity Heritage Library, the world's largest open access digital library for biodiversity literature and archives. Visit BHL at https://www.biodiversitylibrary.org. 